\title{
Changing Spatiotemporal Patterns of 5- and 10-Day Illinois Heavy Precipitation Amounts, 1900-2018
}

\author{
DAVID CHANGNON AND ViTTORIO A. GENSINI \\ Department of Geographic and Atmospheric Sciences, Northern Illinois University, DeKalb, Illinois
}

(Manuscript received 19 December 2018, in final form 14 May 2019)

\begin{abstract}
This study examined the spatiotemporal variability associated with 5-/10-day heavy precipitation amounts for 48 high-quality and long-duration (1900-2018) stations in Illinois. The top five seasonal and annual heavy precipitation amounts for each duration were determined and examined for each station. Annual and seasonal spatial patterns generally showed a trend of decreasing precipitation amounts as one moved northward through Illinois. Spatial distributions of the top seasonal amounts exhibited the highest values in boreal spring and summer, with the lowest values during winter. Temporal analysis of the top five 5- and 10-day amounts from 1900 to 2018 indicated an increasing trend with a higher frequencies in the 2000-18 period for spring, summer, winter, and annual time periods (statistically significant for spring and annual). No trend was found in autumn heavy precipitation occurrence. In addition, heavy precipitation events were examined in the context of the background atmospheric environment using the Twentieth Century Reanalysis. Eventaveraged precipitable water values were shown to scale linearly with total precipitation in the winter season. Low-level circulation fields indicate that the most widespread heavy rain episodes occur when a synoptic anticyclone is positioned off the coast of the eastern United States. Results from this study suggest that design values used for hydrologic structures should be reevaluated given recent observations.
\end{abstract}

\section{Introduction and background}

April 2013 was unusually wet across Illinois. During the middle of the month, heavy rainfall occurred on numerous days leading to widespread record flooding levels along many central and northern Illinois rivers and noteworthy economic losses. Five- and 10-day rainfall totals during the periods 15-19 and 10-19 April identified two southwest-tonortheast swaths of heavy rainfall exceeding $\approx 150 \mathrm{~mm}$ (Figs. 1a,b). These swaths, which covered about half the state, inundated low-lying subdivisions, businesses, and communities, and caused record flooding levels along the Des Plaines, Vermillion, DuPage, Fox, Spoon, Mackinaw, and Illinois Rivers (National Weather Service 2013a,b). Numerous roads in areas experiencing heavy rainfall were impassible for several days, including parts of Interstate 74 in Peoria County, and hundreds of homeowners were evacuated when a levee was breached on the Illinois River near Marseilles. These unusually heavy rainfall periods were linked to one fatality and direct economic losses estimated at $\$ 400$ million USD in Illinois (National Weather Service 2014). Prolonged

\footnotetext{
Corresponding author: David Changnon, dchangnon@niu.edu
}

heavy rainfall events are a common occurrence in the U.S. Midwest and can cause widespread flooding impacting activities in both urban and rural areas.

Depending on soil moisture conditions from antecedent precipitation and vegetation cover at the time of the heavy rainfall event, local or regional flooding can be enhanced or diminished. In Illinois, these widespread events can occur in any month; however, local precipitation amounts are generally higher during the warmest parts of the year when the warmer atmosphere sustains greater precipitable water values (Angel and Huff 1995), and the mechanism is typically convective. Rainfall frequency of extreme hydroclimatic events have long been studied (Yarnell 1935; Hershfield 1961; Changnon 1983; Huff and Changnon 1987; Huff and Angel 1988; Kunkel et al. 1993, 2003; Kunkel 2003; Groisman et al. 2001, 2005; Feng et al. 2016; Easterling et al. 2017; Martinez-Villalobos and Neelin 2018) and used to develop important benchmark values used in the design of hydrologic structures such as dams, bridges, levees, retention/detention ponds, and culverts (Huff and Semonin 1960; Huff 1980; Huff and Changnon 1987; Faragó and Katz 1990). Analyses of heavy rainstorms and local and regional flooding occurrences in Illinois have shown a strong positive relationship 


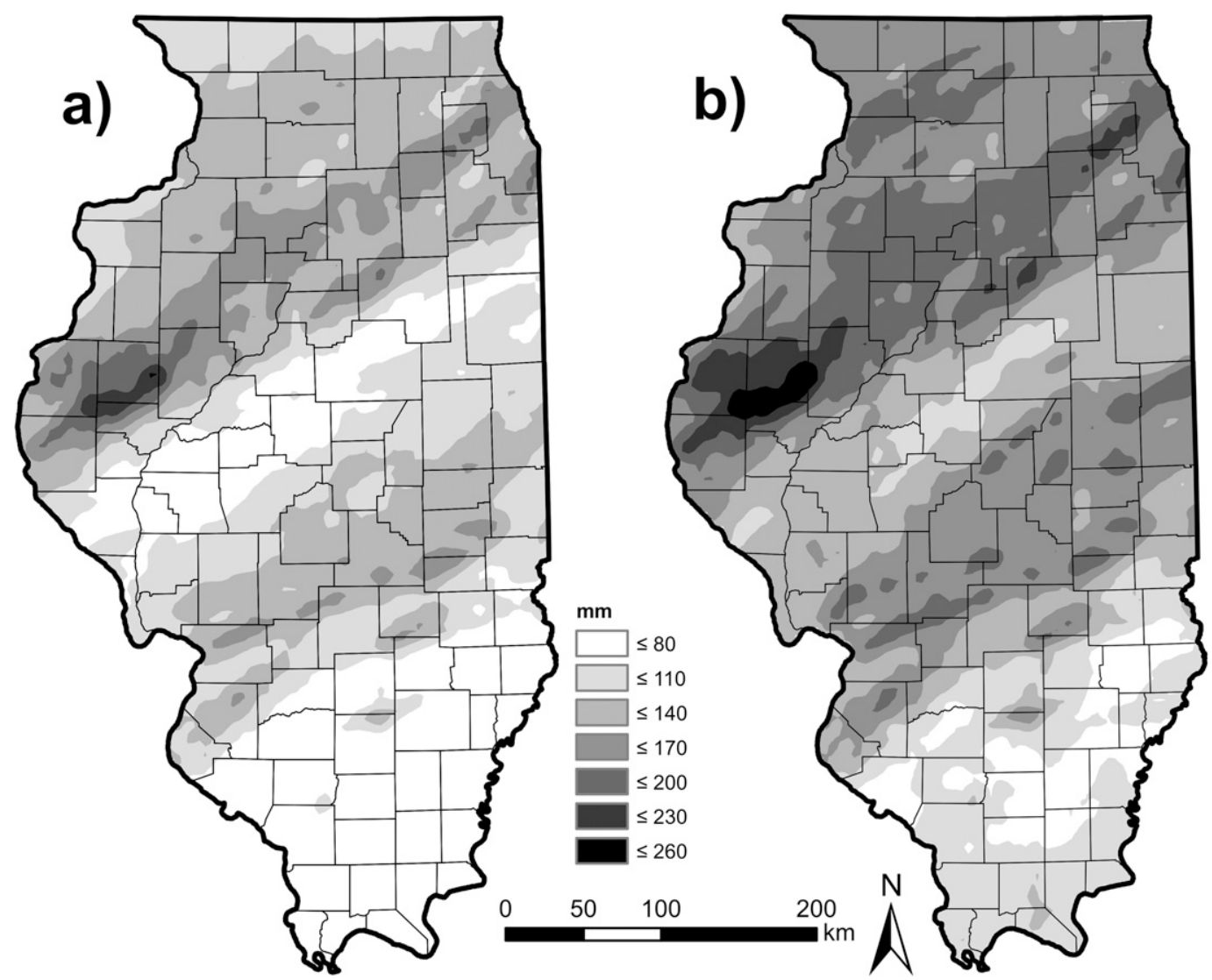

FIG. 1. Total precipitation (mm) for the (a) 5- and (b) 10-day period ending 19 Apr 2013. Precipitation data obtained from the PRISM Climate Group, Oregon State University (http://prism.oregonstate.edu).

over time (Changnon 1983; Changnon et al. 1996; Groisman et al. 2001; Changnon and Changnon 2004). A number of publications have evaluated 1- and 2-day extreme precipitation events in Illinois (Huff and Semonin 1960; Huff and Changnon 1961; Huff 1979; Easterling et al. 2017). Many of these studies have examined the causes of such extreme events, those producing more than $200 \mathrm{~mm}$ at a point, and have found that most are associated with warm-season thunderstorm complexes that train over the same area for periods that generally exceed $12 \mathrm{~h}$ (Changnon 1957; Huff 1979; Changnon and Kunkel 1999; Changnon 2001; Changnon and Westcott 2002; Changnon and Changnon 2004). Remnants from a tropical storm were determined to be the primary cause for anomalous Illinois precipitation amounts in September 1961 and 2008 (Gensini et al. 2011).

In addition, the increased frequency of short duration, 1-/2-day precipitation amounts in the U.S. Midwest since 1900 has been noted in a number of recent studies (Huff and Angel 1988; Kunkel et al. 2003; Groisman et al. 2005; Easterling et al. 2017). Many studies have examined the relationship of these increases, both in the frequency and amount of rainfall experienced, to enhanced greenhouse gas concentrations associated with anthropogenic climate change (Meehl et al. 2000) and changes in large-scale circulation patterns (Yu et al. 2016). The spatial patterns and temporal trends in longer-duration events have not been sufficiently studied, but such information could be particularly useful for assisting hydrological structure design. Results from this research could provide further impetus to update rainfall frequency distributions for areas not only in Illinois, but throughout portions of the Midwest.

\section{Data and methods}

Illinois has long had a history of quality National Weather Service (NWS) daily precipitation records from which to examine heavy precipitation events (Changnon 1957; Huff and Changnon 1961; Changnon 1983; Huff and Angel 1988). Huff and Angel (1988) analyzed daily precipitation records for the period 1901-83 for 61 Illinois NWS cooperative weather stations. These and other long-term Illinois NWS station records were examined in this study, focusing on the 119-yr period 1900-2018. A group of 48 stations with less than $3 \%$ of all daily records missing were 
selected for this study (Fig. 2). Two of the stations had combined records (Sycamore/DeKalb and Freeport) and station displacements occurred at some of the other 46 stations. However, previous research indicates that these small changes have little impact on long-term rainfall measurements (Changnon and Kunkel 2006). The stations are not equally spatially distributed across Illinois, which may have some influence on the presented statistical results. However, the stations shown in Fig. 2 represent an appropriate representation for understanding the climatology of heavy precipitation amounts at 5- and 10-day temporal epochs (Huff and Angel 1988).

The top five annual and seasonal [winter (DJF); spring (MAM); summer (JAA); autumn, (SON)] independent 5- and 10-day precipitation amounts and related dates of occurrence were noted for the selected 48 stations and referred to as events. Events were acquired from the Midwestern Regional Climate Center (MRCC) Application Tools Environment (cli-MATE) web-query tool (https://mrcc.illinois.edu/CLIMATE/). Within any top 5- or 10-day event, precipitation did not necessarily occur on every day in the period. These events are simply the largest precipitation totals for a given 5- or 10-day period within a year or each season. The top five events were chosen for each epoch to provide an adequate sample of these extreme events. Two events were considered independent if they were separated by 5 or more days. For example, if one station experienced one of its top five winter 10-day heavy events from 2 to 11 December 1982 and a second event from 22 to 31 December 1982, these events were considered independent. Two independent heavy precipitation periods in a given season only occurred at 7 of the 48 Illinois stations. An event was counted in a specific season if the 5- or 10-day event started no earlier than the first day of the season (i.e., 1 March for spring) but would be counted as part of a specific season if the event began on the last day of the season (i.e., 31 August for summer).

The top 5- and 10-day heavy precipitation amounts were examined spatially and temporally for each season and for the entire annual cycle. Temporal variability during the 1900-2018 period was evaluated in two ways: 1 ) the time series of the annual and seasonal number of stations experiencing a 5- or 10-day heavy precipitation event, and 2) the frequency distribution of stations in 20 -yr periods (1900-19, ..., 2000-18).

Five- and 10-day heavy precipitation episodes were also examined in space and time. We define an episode when $20 \%$ or more $(\geq 10)$ stations experienced a top five 5 - or 10 -day heavy precipitation amount at the same time. When identifying 5-day heavy precipitation episodes based on all station records, it was expected that 5-day events would

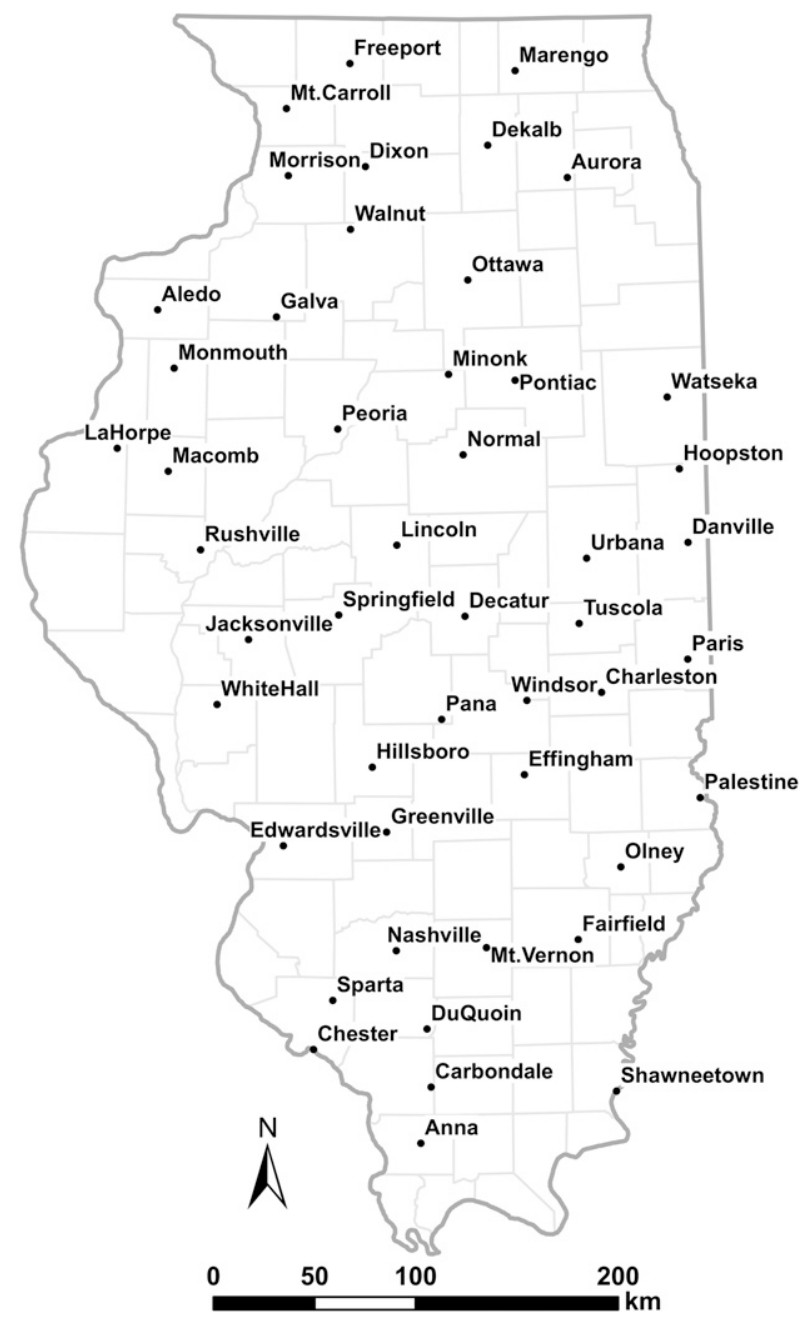

FIG. 2. 48 NWS cooperative weather stations used in this study over the period 1900-2018.

be slightly different (e.g., 15-19 July vs 16-20 July), based on differences in observing times (a.m. vs p.m.) or movement/timing of precipitation producing weather systems. As long as the heavy precipitation 5-day event at 10 or more stations overlapped partially in time with each other, they were considered to be part of the same heavy precipitation episode. The same analysis was conducted for 10-day episodes.

Finally, the Twentieth Century Reanalysis, version 2c (V2c), dataset (Compo et al. 2011) was used to diagnose atmospheric conditions present during these anomalous events and episodes. Precipitable water (PWAT) values were extracted for each 5- and 10-day event by station to determine background moisture availability for precipitation. Daily ensemble mean PWAT values were aggregated and averaged for all top five 5- and 10-day heavy precipitation events. The Twentieth Century Reanalysis is a best-guess reanalysis dataset that uses 


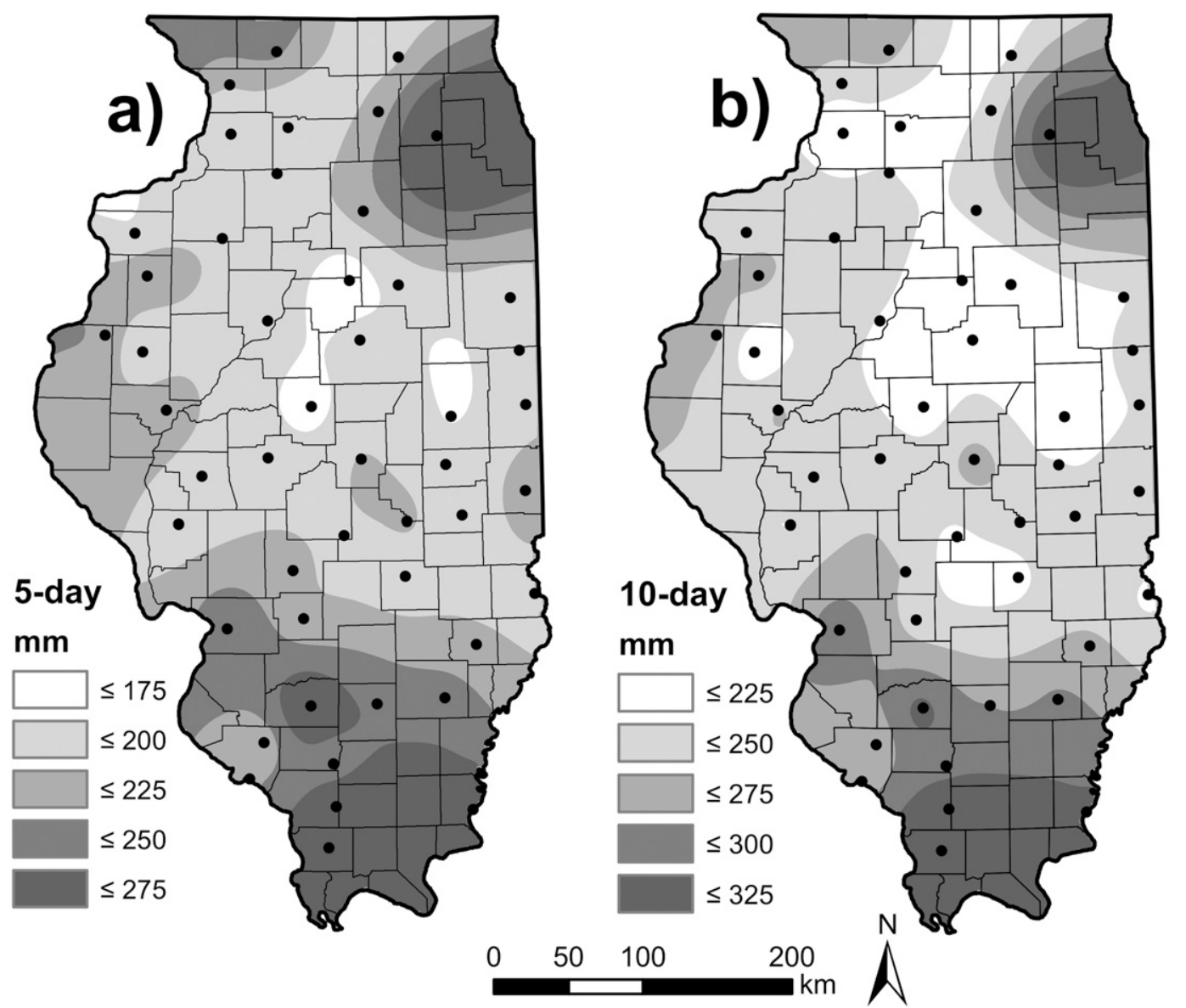

FIG. 3. Average of the top five (a) 5- and (b) 10-day heavy precipitation events from 1900-2018. Black dots indicate the NWS cooperative stations used in the contour analysis.

surface pressure to derive the vertical structure of the atmosphere (Compo et al. 2006). We also created $850-\mathrm{mb}(1 \mathrm{mb}=1 \mathrm{hPa})$ wind speed and vector anomaly composites for 5 and 10-day episodes by season, and 850-mb circulation anomalies were created using the 1981-2010 climatology.

\section{Results}

\section{a. Annual}

The average of the top five 5- and 10-day annual heavy precipitation totals generally decreased from south to north across the state (Fig. 3). The average of the top 5-day annual heavy precipitation amounts was generally higher than $250 \mathrm{~mm}(\approx 10 \mathrm{in}$.) in the southern third of the state. The lowest values $(\leq 180 \mathrm{~mm})$ were in central Illinois. Maximum values were greater than $250 \mathrm{~mm}$ in the northeastern and northwestern corners of the state with a peak value of $291 \mathrm{~mm}$ at Aurora. Similarly, the 10-day pattern, based on averaging the top five amounts, exhibited a maximum in southern
Illinois (Anna's maximum was $326 \mathrm{~mm}$ ), generally decreasing northward with a large area in central and north central Illinois experiencing a 10-day average value of less than $250 \mathrm{~mm}$. Values greater than $300 \mathrm{~mm}$ were found in the southern one-third and northeastern Illinois, with Aurora reporting a top five average 10-day amount of $321 \mathrm{~mm}$ that included the infamous flooding event starting on 16 July 1996 (Changnon and Kunkel 1999).

\section{b. Spring}

Average of the top five 5- and 10-day boreal spring heavy precipitation amounts exhibited similar patterns (Figs. 4a,b). The average 5-day spring amount was generally more than $180 \mathrm{~mm}$ south of an Edwardsvilleto-Paris line ( $319 \mathrm{~mm}$ at Anna), with an axis of values less than $150 \mathrm{~mm}$ from central Illinois northward to the Wisconsin border. The average 10-day values were generally more than $250 \mathrm{~mm}$ across the southern one-half of the state (maximum of $326 \mathrm{~mm}$ at Anna that included an event in April 2011) with a similar minimum running from central Illinois northward. Ten of the 48 stations 


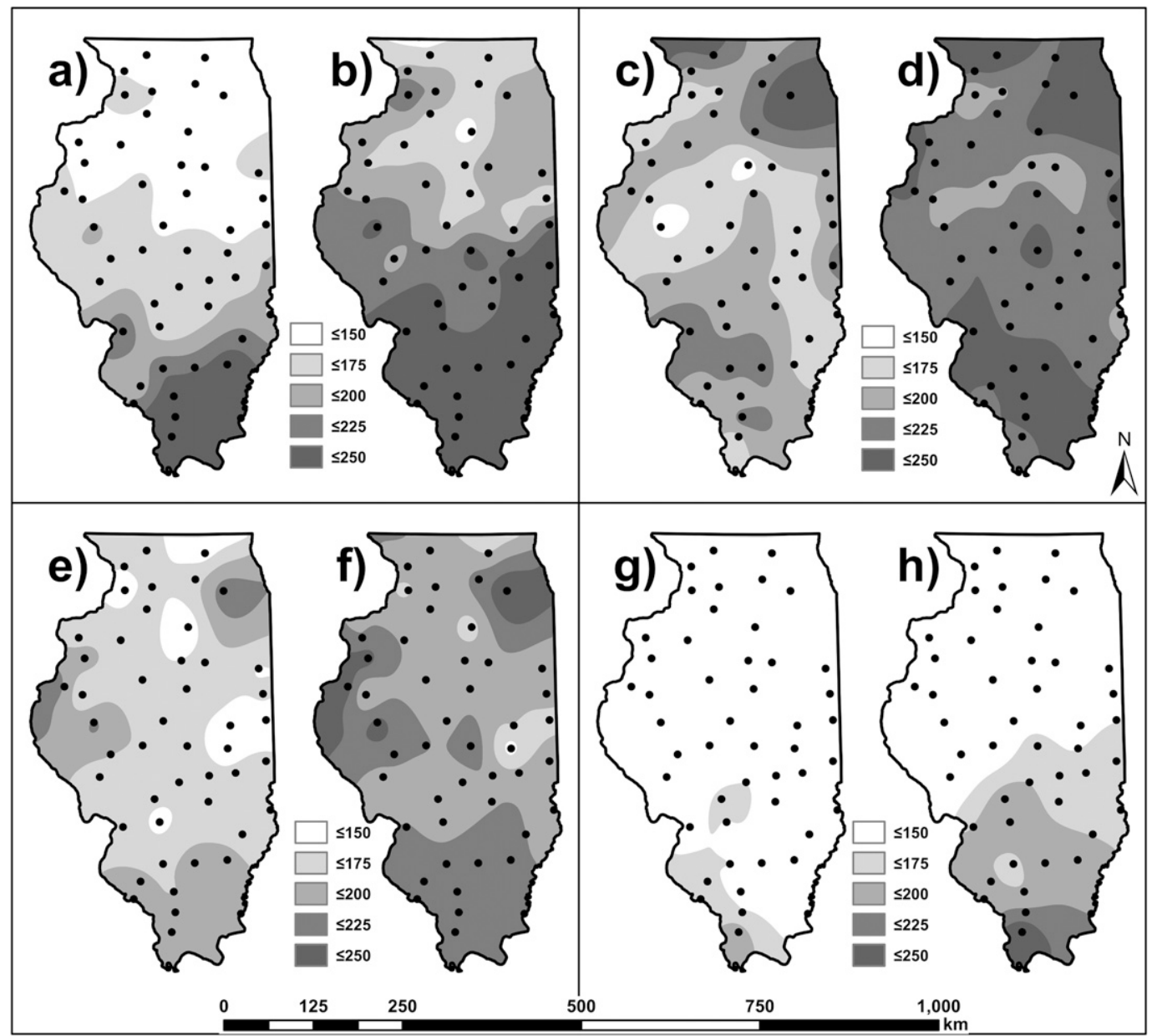

FIG. 4. Average of the top five spring (a) 5- and (b) 10-day, summer (c) 5- and (d) 10-day, autumn (e) 5- and (f) 10-day, and winter (g) 5- and (h) 10-day heavy precipitation events (mm) from 1900-2018. Black dots indicate the NWS cooperative stations used in the contour analysis.

experienced their highest 5-day annual heavy precipitation value during spring, with 8 of 10 stations located in the southern one-third of the state. Twelve of the stations had their highest 10-day annual heavy precipitation amount during spring, with 11 of 12 located in the southern half of the state.

\section{c. Summer}

Slightly more than half of stations ( 27 for 5 day and 25 for 10 day) experienced their annual maximum amount during the summer, and these stations were generally located north of a line from Saint Louis, Missouri, to Vincennes, Indiana. The summer spatial pattern for both the 5- and 10-day pattern was dominated by a number of relative maximums and minimums randomly distributed across the state (Figs. 4c,d). Notable average maximums were located near Nashville/Mount Vernon in southern Illinois and at Aurora and Freeport in northern Illinois. Aurora experienced the summer statewide maximum 5- and 10-day total, and that occurred during the record northeastern Illinois floods of July 1996 (Changnon and Kunkel 1999).

\section{d. Autumn}

Autumn station top five averaged amounts were generally less than those in summer and did not vary as much (150-290 $\mathrm{mm}$ for the top five average 5-day amounts; 170 $360 \mathrm{~mm}$ for top five average 10-day amounts). Similar to the summer period, areas of relative maximum and minimum (for both 5 and 10-day average amounts) were also scattered (Figs. 4e,f). Relative maximums were found in western and northeastern Illinois. Aurora took honors for the statewide autumn maximum for the 5- and 10-day amounts. These extreme amounts were associated with heavy precipitation events in October 1954. Eleven of the 48 stations experienced their highest annual 5-day precipitation amount in autumn, while 10 stations had their highest 10-day annual precipitation amount during autumn, with most occurring in central or northern Illinois. 

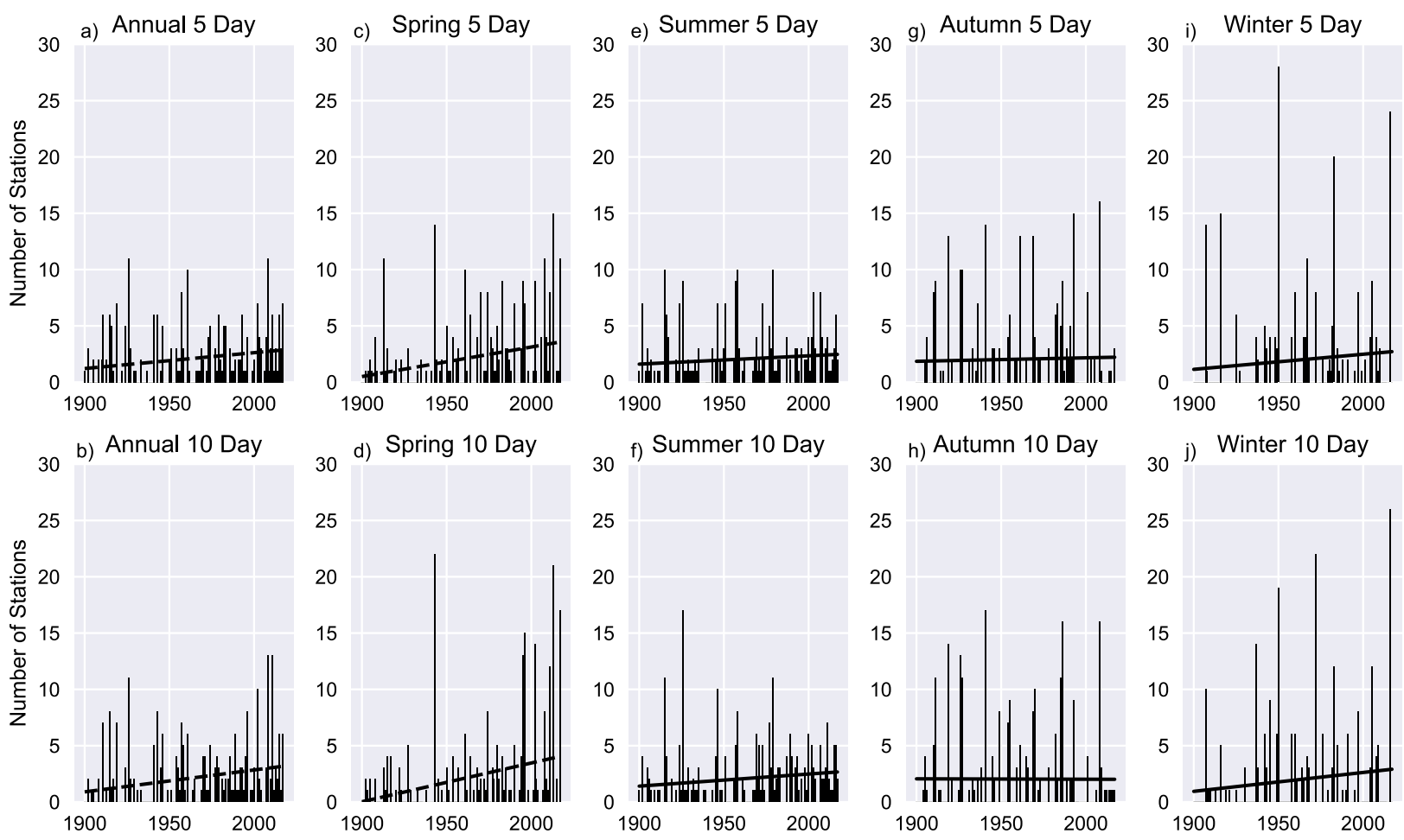

FIG. 5. Interannual variability (1900-2018) of the number of stations experiencing a top five 5-day or 10-day heavy precipitation event. Least squared regression lines are plotted and shown in dashed line style if significant at the $\alpha=0.05$ level.

\section{e. Winter}

Winter 5- and 10-day top five average amounts were generally the lowest of the four seasons and showed a general decrease from south to north across the state with most of the northern half of the state experiencing a winter average maximum less than $150 \mathrm{~mm}$ (Figs. 4g,h). Relative winter maximum values were found near the southern tip of the state, and in an area northeast of Saint Louis, Missouri. Only 1 station, Greenville, Illinois, experienced its highest 10-day annual precipitation amount in winter.

\section{f. Temporal distributions}

The seasonal distribution of highest annual 5- and 10-day precipitation amounts indicates that summer is not the only season when these extreme events occur. A study by Angel and Huff (1995) noted that cool season extreme precipitation amounts were common in southern Illinois; however, this study found for longer-duration periods, some central and northern Illinois stations experience their top values in autumn. The temporal distribution of the number of Illinois stations experiencing one of their top five annual 5- and 10-day heavy precipitation amounts showed a great deal of interannual variability and slight increasing trends through the 119-yr period (Fig. 5a). The annual 5 -day time series values ranged from zero in numerous years to a high of 11 stations in 1926 and 2008, and there were more years with no stations experiencing one of these precipitation extremes in a given year in the period prior to 1965. Although the temporal pattern for the annual 10-day heavy precipitation amounts was similar, there are some differences (Fig. 5b). Again, values ranged from zero experienced in a number of years to a high of 13 experienced in 2008 and 2011. Both charts show a minimum in frequency during the 1930s. The least squared regression slopes for both annual time series is associated with a significant increase in frequency of top five heavy precipitation amounts (Table 1).

Time series plots were also developed and evaluated for each season (Figs. $5 \mathrm{c}-\mathrm{j}$ ). There were six springs where 10 or more stations experienced a 5-day heavy precipitation

TABLE 1. Least squared regression line slopes for annual and seasonal top five 5- and 10-day heavy precipitation events, 1900 2018. Slopes in bold font are significant at the $\alpha=0.05$ level.

\begin{tabular}{lcc}
\hline \hline & \multicolumn{2}{c}{ Slope } \\
\cline { 2 - 3 } Period & 5 day & 10 day \\
\hline Annual & $\mathbf{+ 0 . 0 1 3}$ & $\mathbf{+ 0 . 0 1 8}$ \\
Spring & $\mathbf{+ 0 . 0 2 5}$ & $\mathbf{+ 0 . 0 3 3}$ \\
Summer & +0.010 & +0.006 \\
Autumn & +0.002 & -0.001 \\
Winter & +0.018 & +0.021 \\
\hline
\end{tabular}



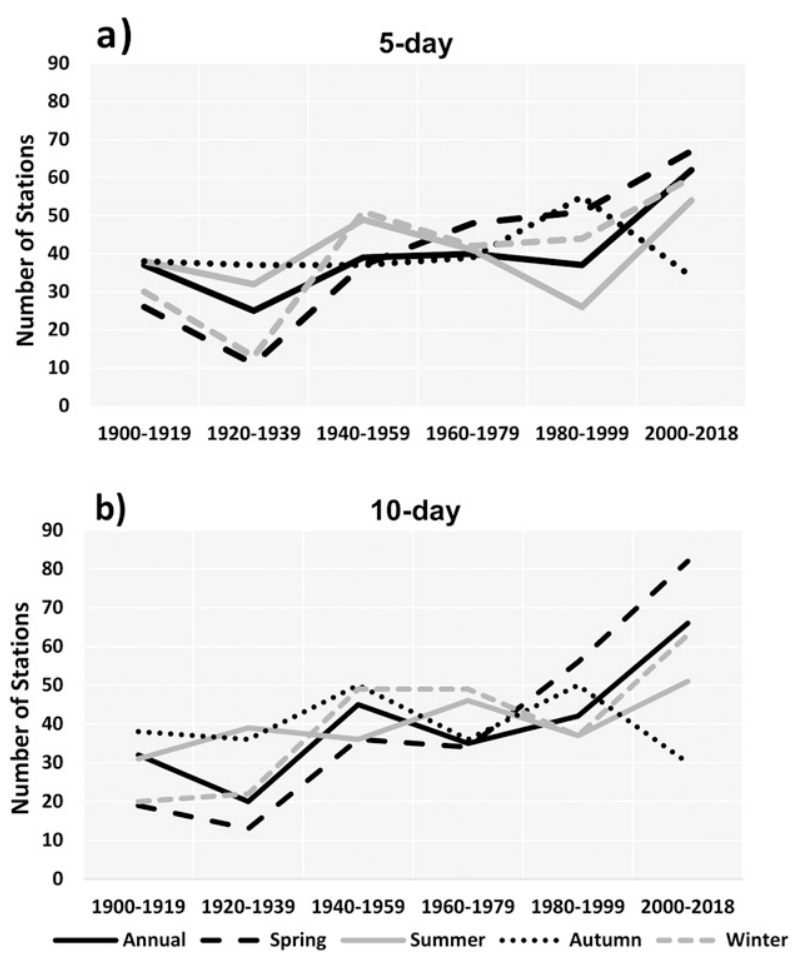

FIG. 6. Frequency of stations experiencing one of their top five annual or seasonal (a) 5- and (b) 10-day heavy precipitation events by 20 -yr epoch, $1900-2018$.

amount, and seven springs where 10 or more stations experienced a 10-day heavy precipitation amount. Six of those seven anomalously high count spring years occurred after 1994. Both spring time series exhibit the greatest seasonal increase over time (Table 1) and were significant. Summer experienced the fewest number of high-count years (again, events impacting 10 or more stations) with three years for 5-day heavy precipitation amounts and 4 for 10-day heavy precipitation amounts. A majority of these summer high-count years occurred before 1960 and the increase in occurrence of 5-/10-day heavy precipitation amounts over the 119-yr period was smaller than that found in spring (Table 1). Since 1980, there have been no summers when a large number of stations $(\geq 10)$ are impacted suggesting that these heavy precipitation amounts may be increasingly caused by localized thunderstorm complexes that impact smaller areas. Autumn experienced eight years having 5-day heavy precipitation amounts at 10 or more stations, and nine autumns had 10-day heavy precipitation amounts at 10 or more stations, with most of these years occurring before 1960. A couple of these highcount years were related to remnants from tropical storms [e.g., 1961 (Carla) and 2008 (Ike)]. The least squared regression slopes were near zero for both time series indicating little change in occurrence of autumn 5-/10-day heavy precipitation events in Illinois. Winter heavy
TABLE 2. Percentage of top five 5- and 10-day annual and seasonal heavy precipitation events in the 2000-18 and 1980-2018 periods.

\begin{tabular}{lccccc}
\hline \hline & \multicolumn{2}{c}{$2000-18$} & & \multicolumn{2}{c}{$1980-2018$} \\
\cline { 2 - 3 } \cline { 6 - 6 } Period & 5 day & 10 day & & 5 day & 10 day \\
\hline Annual & $25.8 \%$ & $27.5 \%$ & & $41.3 \%$ & $45.0 \%$ \\
Spring & $27.9 \%$ & $34.2 \%$ & & $49.2 \%$ & $57.5 \%$ \\
Summer & $22.5 \%$ & $21.3 \%$ & & $33.3 \%$ & $36.7 \%$ \\
Autumn & $14.0 \%$ & $12.5 \%$ & & $37.0 \%$ & $33.3 \%$ \\
Winter & $25.0 \%$ & $26.3 \%$ & & $43.3 \%$ & $41.7 \%$ \\
\hline
\end{tabular}

precipitation events were also clustered in fewer years, with seven winters having 5-day heavy precipitation amounts at 10 or more stations, and eight winters having 10-day heavy precipitation amounts at 10 or more stations. A majority of these events occurred in the second half of the period, and significantly impacted the slopes of the least squared regression lines (Table 1).

The frequency of stations experiencing one of their top five annual and seasonal 5- and 10-day heavy precipitation amounts was examined in independent 20 -yr periods (i.e., $1900-19, \ldots, 2000-18)$. The five trend lines (annual and each season) for the 5-day heavy precipitation amounts varied through the study period, however, for annual, spring, summer, and winter, the trend was generally increasing with the highest 20 -yr value occurring in the 2000-18 period (Fig. 6a). The spring, winter and annual increasing trends appear more noteworthy than the increasing trend for summer. The trend for autumn appears generally flat with its lowest 20 -yr value occurring in the last period. Similar results were found when examining the trends for the 10-day heavy precipitation amounts (Fig. 6b). Once again, the largest increasing trends occurred in spring, followed by winter, with the only trend ending with a relative low in the last period being autumn. To examine how the frequency of extreme 5- and 10-day heavy precipitation events has changed since Huff and Angel (1988), we computed the percentage of top five precipitation amounts in the last period (2000-18) as well as the last 39 years (1980-2018). If their occurrence was randomly distributed through time, one would expect approximately $16 \%$ in the last period and $32.7 \%$ in the last 39 years (Table 2). Values presented in Table 2 indicate that the frequency of heavy precipitation amounts over the last period and the last 39 years has experienced a notable increase when examined at the annual, spring, and winter time frames. Summer increases appear greater during the last period than over the 39 -yr period, while the autumn values indicate a below average frequency in the last 20 years.

\section{g. Unique spatial coverage events}

Additional analyses examined those episodes when more than $20 \%$ (10 or more) of the selected Illinois 

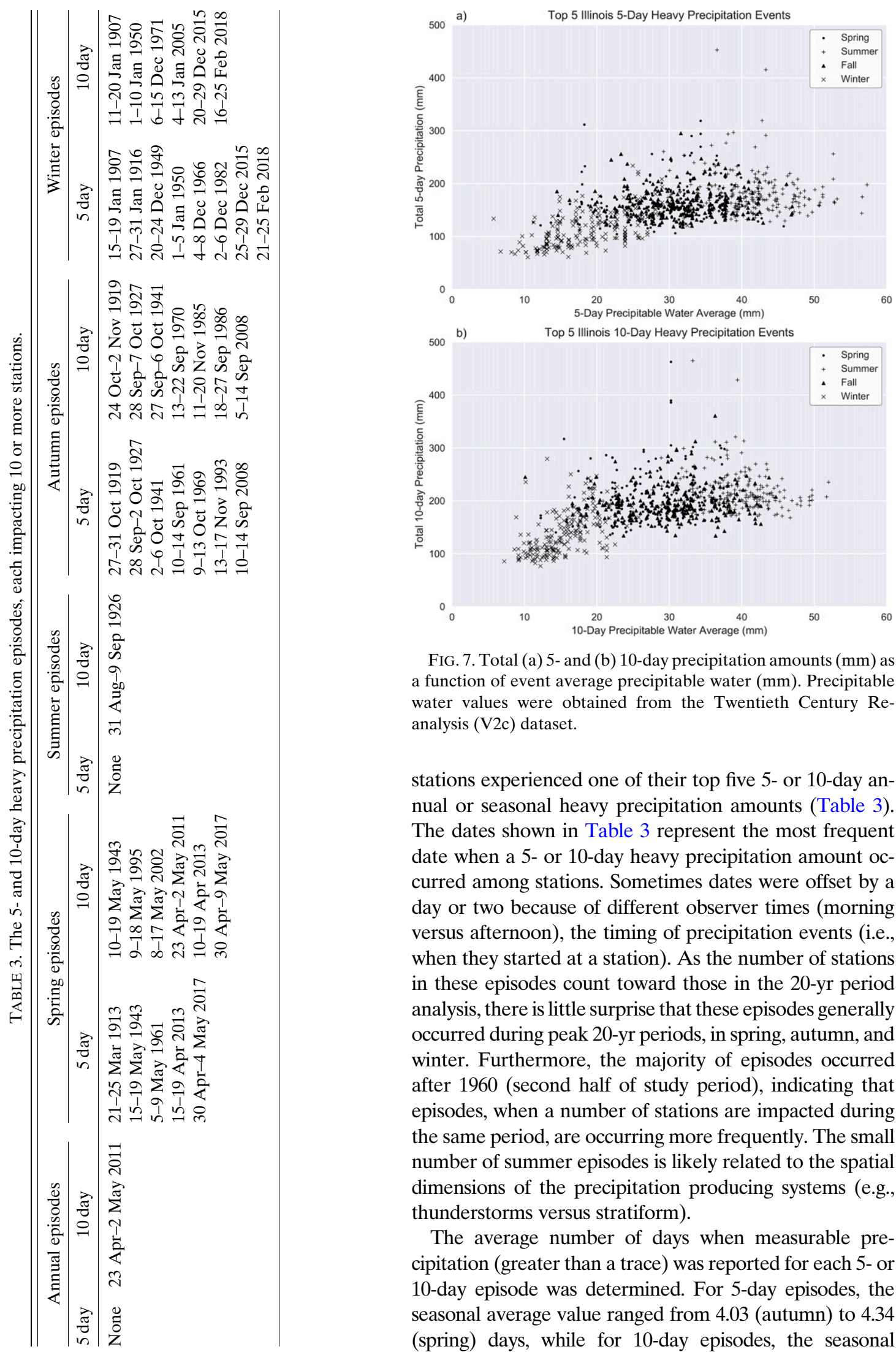

FIG. 7. Total (a) 5- and (b) 10-day precipitation amounts (mm) as a function of event average precipitable water $(\mathrm{mm})$. Precipitable water values were obtained from the Twentieth Century Reanalysis (V2c) dataset.

stations experienced one of their top five 5- or 10-day annual or seasonal heavy precipitation amounts (Table 3 ). The dates shown in Table 3 represent the most frequent date when a 5- or 10-day heavy precipitation amount occurred among stations. Sometimes dates were offset by a day or two because of different observer times (morning versus afternoon), the timing of precipitation events (i.e., when they started at a station). As the number of stations in these episodes count toward those in the 20-yr period analysis, there is little surprise that these episodes generally occurred during peak 20 -yr periods, in spring, autumn, and winter. Furthermore, the majority of episodes occurred after 1960 (second half of study period), indicating that episodes, when a number of stations are impacted during the same period, are occurring more frequently. The small number of summer episodes is likely related to the spatial dimensions of the precipitation producing systems (e.g., thunderstorms versus stratiform).

The average number of days when measurable precipitation (greater than a trace) was reported for each 5- or 10-day episode was determined. For 5-day episodes, the seasonal average value ranged from 4.03 (autumn) to 4.34 (spring) days, while for 10-day episodes, the seasonal 
a) Average Spring (MAM) $850 \mathrm{mb}$ Wind Anomaly (5-day Episodes)

a) $150^{\circ} \mathrm{W} \quad 135^{\circ} \mathrm{W} \quad 120^{\circ} \mathrm{W} \quad 105^{\circ} \mathrm{W} \quad 90^{\circ} \mathrm{W} \quad 75^{\circ} \mathrm{W} \quad 60^{\circ} \mathrm{W}$

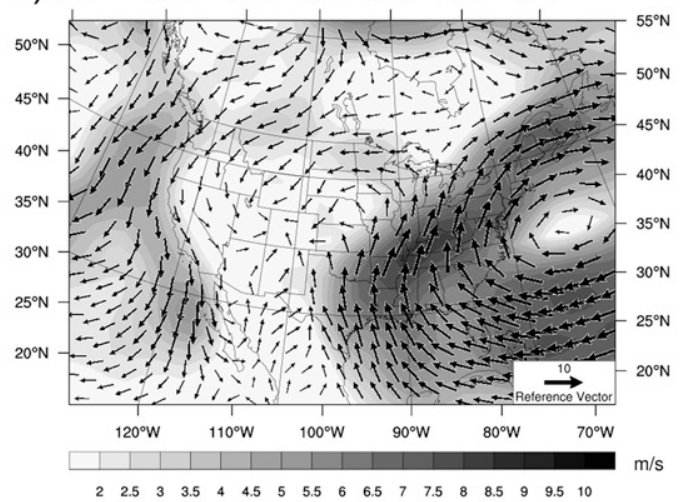

C) Average Autumn (SON) $850 \mathrm{mb}$ Wind Anomaly (5-day Episodes)

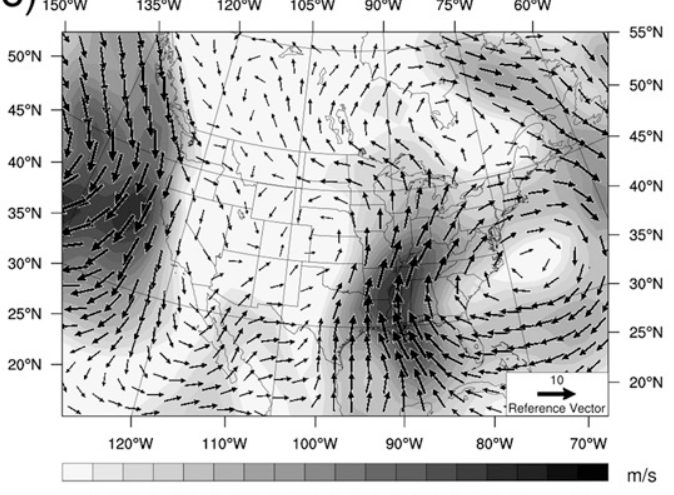

$\begin{array}{lllllllllllllllll}2 & 2.5 & 3 & 3.5 & 4 & 4.5 & 5 & 5.5 & 6 & 6.5 & 7 & 7.5 & 8 & 8.5 & 9 & 9.5 & 10\end{array}$

e) Average Winter (DJF) $850 \mathrm{mb}$ Wind Anomaly (5-day Episodes)

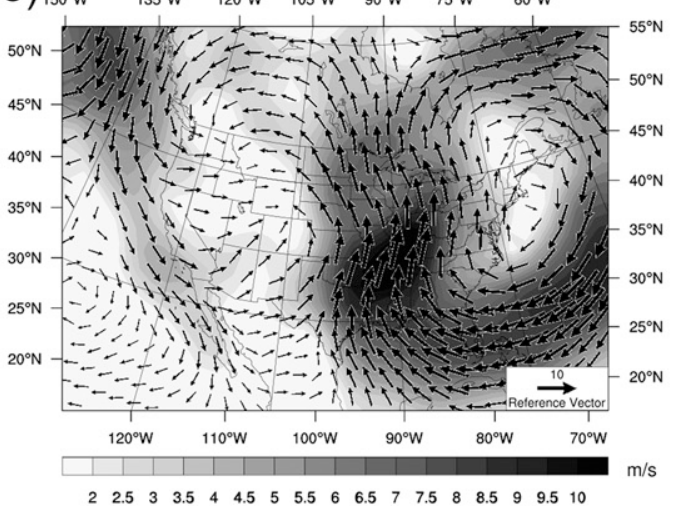

b) Average Spring (MAM) $850 \mathrm{mb}$ Wind Anomaly (10-day Episodes) D) $150^{\circ} \mathrm{W} \quad 135^{\circ} \mathrm{W} \quad 120^{\circ} \mathrm{W} \quad 105^{\circ} \mathrm{W} \quad 90^{\circ} \mathrm{W} \quad 75^{\circ} \mathrm{W} \quad 60^{\circ} \mathrm{W}$

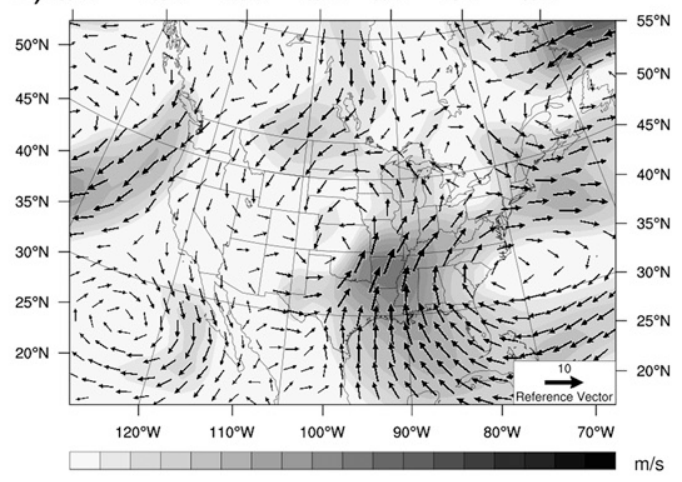

$\begin{array}{lllllllllllllllll}2 & 2.5 & 3 & 3.5 & 4 & 4.5 & 5 & 5.5 & 6 & 6.5 & 7 & 7.5 & 8 & 8.5 & 9 & 9.5 & 10\end{array}$

d) Average Autumn (SON) $850 \mathrm{mb}$ Wind Anomaly (10-day Episodes)

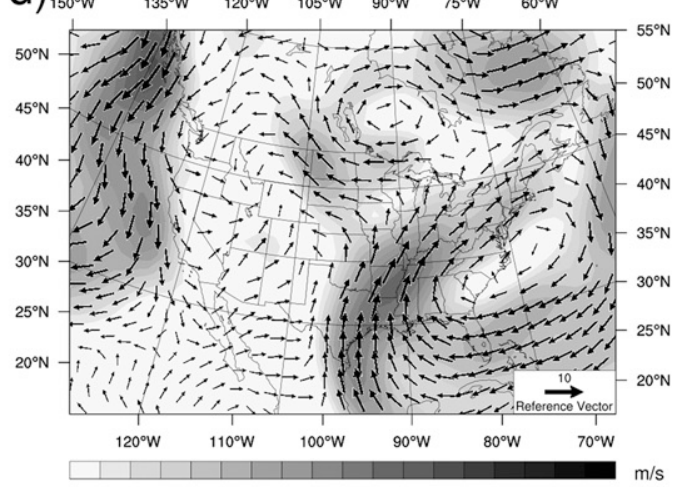

$\begin{array}{lllllllllllllllll}2 & 2.5 & 3 & 3.5 & 4 & 4.5 & 5 & 5.5 & 6 & 6.5 & 7 & 7.5 & 8 & 8.5 & 9 & 9.5 & 10\end{array}$

f) Average Winter (DJF) $850 \mathrm{mb}$ Wind Anomaly (10-day Episodes)

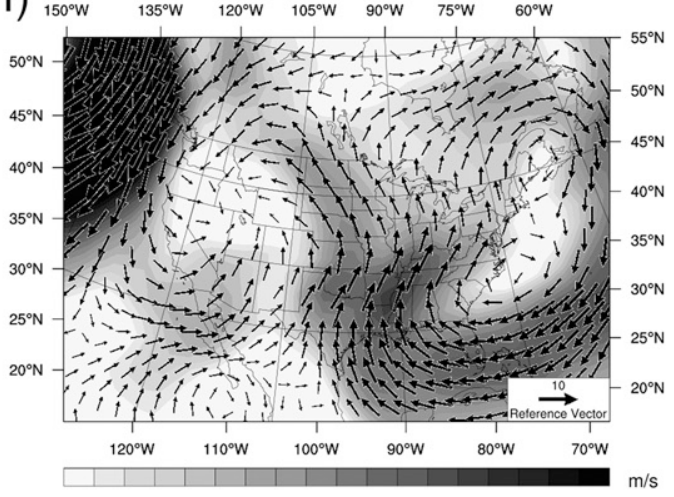

$\begin{array}{lllllllllllllllll}2 & 2.5 & 3 & 3.5 & 4 & 4.5 & 5 & 5.5 & 6 & 6.5 & 7 & 7.5 & 8 & 8.5 & 9 & 9.5 & 10\end{array}$

FIG. 8. Composite 850-mb wind vector and isotach (fill) anomalies $\left(\mathrm{m} \mathrm{s}^{-1}\right)$ for (a) spring 5-day episodes, (b) spring 10-day episodes, (c) autumn 5-day episodes, (d) autumn 10-day episodes, (e) winter 5-day episodes, and (f) winter 10-day episodes. Anomaly fields were obtained from the Twentieth Century Reanalysis (V2c) dataset and calculated from the 1981-2010 averages. Summer and annual not shown because of $N \leq 1$. Composite dates can be found in Table 3 .

average value ranged from 6.99 (winter) to 7.21 (autumn) days (Table 3). This analysis suggests that 5- and 10-day episodes are associated with multiple days with measurable precipitation. Thus, although some of these events may be associated with heavy precipitation that primarily occurs over 1 to 2 days within a 5- or 10-day period, these results suggest that examining 5- to 10-day rainfall periods is justified. There did not seem to be a preference for the spatial distribution of these 5- or 10-day episodes.

\section{h. Environmental relationships}

Final analysis involved the investigation of these 5and 10-day heavy precipitation events as related to the background atmospheric environment. First, for each of 
these 5- and 10-day events, the average daily PWAT values were extracted from 20CR. PWAT was shown to scale linearly for the winter season (i.e., as daily average PWAT increases, so too do rainfall totals). This relationship was not as clear for other seasons, but an apparent seasonal cycle emerges when comparing all 5-day (Fig. 7a) and 10-day events (Fig. 7b). This analysis suggest that the background moisture availability is more important in the typically nonconvective winter season, and is less important in the summer convective season and autumn because of possible tropical contributions. There also appear to be some important discriminatory thresholds that forecasters could use if expecting these events given the season. Further exploratory spatial analyses (not shown) indicated that areas impacted by a 5- or 10-day episode were generally located within an area of high PWAT anomaly values $(+5$ to $+10 \mathrm{~mm})$, or frequently located along/near the northern (or northwestern) edge of the higher PWAT anomaly values, in an area of large PWAT gradient. These transitional PWAT areas, often located just along and south of a frontal zone, are notable as atmospheric moisture often pools in these locations assisting with a continual feed of moisture for heavy precipitation events.

In addition to the moisture relationships, atmospheric circulation anomalies were also examined for all 5- and 10-day episodes (dates found in Table 3), to better understand the synoptic weather regimes present during these high-impact episodes that covered large spatial areas. Composite anomalies of $850-\mathrm{mb}$ wind speed and wind vectors were created for spring, autumn, and winter (Fig. 8); 850-mb was chosen for this analysis in an attempt to best diagnose the potential for lower-tropospheric moisture transport. Summer and annual periods were not included in this analysis because of a sample size of $\leq 1$. Strong qualitative similarities exist among all seasons in both the 5- and 10-day periods. Vector anomalies suggest that an average synoptic $850-\mathrm{mb}$ anticyclone is typically present off the coast of the eastern United States, with a center between $30^{\circ}$ and $35^{\circ} \mathrm{N}$ depending on the season. To the west of this feature, southerly flow is found in all composites across large portions of the Mississippi, Tennessee, and Ohio River valleys. This analysis suggests favorable large-scale conditions for low-level poleward moisture transport into the study area and bears a strong resemblance to the positive phases of the Arctic Oscillation (Thompson and Wallace 1998). Further work is needed to examine if/how teleconnections play a role in creating a conducive atmospheric environment for these episodes.

\section{Summary and conclusions}

Heavy 5- and 10-day rainfall amounts have increased in Illinois and this has aided in more frequent and costly flood-related damages. The frequency of top five 5- or 10-day amounts at 48 Illinois long-term stations increased annually and in all seasons except autumn during the study period (1900-2018). The increases for annual and spring were statistically significant at the $\alpha=0.05$ level.

An analysis of 5- and 10-day heavy rainfall episodes, 5- or 10-day periods when 10 or more stations experienced one of their top five heavy rainfall amounts, identified that these episodes have occurred more frequently since 1960 . For these episodes, the number of days with measurable precipitation in a 5- or 10-day period was also determined. On average, 4 of the 5 days in a 5-day episode experienced measurable precipitation, while measurable precipitation fell on an average of 7 of 10 days in a 10-day episode.

In addition, precipitable water values were extracted for each 5- and 10-day heavy rain event and shown to scale linearly during winter events, with a clear seasonal signature. Precipitable water averages during these events suggests that they could be used in anticipation of such events. Composite analysis of low-level circulation fields indicate that the most widespread 5- and 10-day heavy rain episodes occur when a synoptic anticyclone is positioned off the coast of the eastern United States, creating favorable poleward fluxes of low-level moisture from the Gulf of Mexico into the Illinois region.

In an aggregate sense, these results provide further justification to reexamine rainfall frequency distributions for a range of durations across Illinois and underscore the continual need to evaluate the spatiotemporal variability of extremes as our climate continues to change.

Acknowledgments. The authors thank the Midwestern Regional Climate Center for their excellent online data repository (https://mrcc.illinois.edu/CLIMATE/), which helped make this study possible. Three anonymous reviewers also greatly improved the quality of this manuscript.

\section{REFERENCES}

Angel, J. R., and F. A. Huff, 1995: Seasonal distribution of heavy rainfall events in Midwest. J. Water Resour. Plann. Manage., 121, 110-115, https://doi.org/10.1061/(ASCE)0733-9496(1995) 121:1(110).

Changnon, D., D. Fox, and S. Bork, 1996: Differences in warmseason, rainstorm-generated stormflows for northeastern Illinois urbanized basins. J. Amer. Water Resour. Assoc., 32, 1307-1317, https://doi.org/10.1111/j.1752-1688.1996.tb03499.x.

Changnon, S. A., 1957: Thunderstorm-precipitation relations in Illinois. Illinois State Water Survey Tech. Rep., 24 pp., https:// www.ideals.illinois.edu/bitstream/handle/2142/101974/ISWSRI34.pdf? sequence $=1 \&$ isAllowed $=\mathrm{y}$.

_ 1983: Trends in floods and related climate conditions in Illinois. Climatic Change, 5, 341-363, https://doi.org/10.1007/ BF02423530. 
- 2001: Thunderstorm rainfall in the conterminous United States. Bull. Amer. Meteor. Soc., 82, 1925-1940, https://doi.org/10.1175/ 1520-0477(2001)082<1925:TRITCU>2.3.CO;2.

— , and K. E. Kunkel, 1999: Record flood-producing rainstorms of 17-18 July 1996 in the Chicago metropolitan area. Part I: Synoptic and mesoscale features. J. Appl. Meteor., 38, 257-265, https:// doi.org/10.1175/1520-0450(1999)038,0257:RFPROJ.2.0.CO;2.

_ , and N. E. Westcott, 2002: A record number of heavy rainstorms in Chicago in 2001. Trans. Ill. State Acad. Sci., 95, 73-85.

- , and D. Changnon, 2004: Unusual rainstorms in Illinois produced unusual impacts. Trans. Ill. State Acad. Sci., 97, 45-54.

— fecting historical weather records: A case study. J. Atmos. Oceanic Technol., 23, 825-828, https://doi.org/10.1175/JTECH1888.1.

Compo, G. P., and Coauthors, 2011: The Twentieth Century Reanalysis project. Quart. J. Roy. Meteor. Soc., 137, 1-28, https:// doi.org/10.1002/qj.776.

_ J. S. Whitaker, and P. D. Sardeshmukh, 2006: Feasibility of a 100-year reanalysis using only surface pressure data. Bull. Amer. Meteor. Soc., 87, 175-190, https://doi.org/10.1175/ BAMS-87-2-175.

Easterling, D. R., and Coauthors, 2017: Precipitation change in the United States. Climate Science Special Report: Fourth $\mathrm{Na}$ tional Climate Assessment, Vol. I, D. J. Wuebbles et al., Eds., U.S. Global Change Research Program, 207-230, https:// doi.org/10.7930/J0H993CC.

Faragó, T., and R. W. Katz, 1990: Extremes and design values in climatology. WMO-TD 386, $51 \mathrm{pp}$.

Feng, Z., L. R. Leung, S. Hagos, R. A. Houze, C. D. Burleyson, and K. Balaguru, 2016: More frequent intense and long-lived storms dominate the springtime trend in central US rainfall. Nat. Commun., 7, 13429, https://doi.org/10.1038/ncomms13429.

Gensini, V., A. Black, D. Changnon, and S. Changnon, 2011: September 2008 heavy rains in northeast Illinois: Meteorological analysis and impacts. Trans. Ill. State Acad. Sci., 104, 17-33.

Groisman, P. Ya., R. W. Knight, and T. R. Karl, 2001: Heavy precipitation and high streamflow in the contiguous United States: Trends in the twentieth century. Bull. Amer. Meteor. Soc., 82, 219-246, https://doi.org/10.1175/1520-0477(2001)082<0219: HPAHSI > 2.3.CO;2.

,-- , D. R. Easterling, T. R. Karl, G. C. Hegerl, and V. N. Razuvaev, 2005: Trends in intense precipitation in the climate record. J. Climate, 18, 1326-1350, https://doi.org/10.1175/ JCLI3339.1.

Hershfield, D. M., 1961: Rainfall frequency atlas of the United States. Weather Bureau Tech. Paper 40, 65 pp., https:// www.nws.noaa.gov/oh/hdsc/PF_documents/TechnicalPaper_ No40.pdf.

Huff, F. A., 1979: Hydrometeorological characteristics of severe rainstorms in Illinois. Illinois State Water Survey Tech. Rep., 22 pp., https://www.isws.illinois.edu/pubdoc/RI/ ISWSRI-90.pdf.

, 1980: Precipitation relations for use in dam safety project. Illinois State Water Survey Tech. Rep., 22 pp., https:// core.ac.uk/download/pdf/29158230.pdf.
—, and R. G. Semonin, 1960: An investigation of floodproducing storms in Illinois. Topics in Engineering Meteorology, Springer, 50-55.

_ , and S. A. Changnon, 1961: Severe rainstorms in Illinois, 19581959. Illinois State Water Survey Tech. Rep., 74 pp., https:// www.isws.illinois.edu/pubdoc/RI/ISWSRI-42.pdf.

$\longrightarrow$, and - 1987: Temporal changes in design rainfall frequencies in Illinois. Climatic Change, 10, 195-200, https:// doi.org/10.1007/BF00140255.

— , and J. R. Angel, 1988: Frequency distributions and hydroclimatic characteristics of heavy rainstorms in Illinois. Illinois State Water Survey Tech. Rep., 182 pp., https://www.isws.illinois.edu/pubdoc/ B/ISWSB-70.pdf.

Kunkel, K. E., 2003: North American trends in extreme precipitation. Nat. Hazards, 29, 291-305, https://doi.org/10.1023/ A:1023694115864.

— S. A. Changnon, and R. T. Shealy, 1993: Temporal and spatial characteristics of heavy-precipitation events in the Midwest. Mon. Wea. Rev., 121, 858-866, https://doi.org/10.1175/15200493(1993) $121<0858$ :TASCOH $>2.0 . \mathrm{CO} ; 2$.

— D. R. Easterling, K. Redmond, and K. Hubbard, 2003: Temporal variations of extreme precipitation events in the United States: 1895-2000. Geophys. Res. Lett., 30, 1900, https://doi.org/10.1029/2003GL018052.

Martinez-Villalobos, C., and J. D. Neelin, 2018: Shifts in precipitation accumulation extremes during the warm season over the United States. Geophys. Res. Lett., 45, 8586-8595, https://doi.org/10.1029/2018GL078465.

Meehl, G. A., F. Zwiers, J. Evans, T. Knutson, L. Mearns, and P. Whetton, 2000: Trends in extreme weather and climate events: Issues related to modeling extremes in projections of future climate change. Bull. Amer. Meteor. Soc., 81, 427-436, https:// doi.org/10.1175/1520-0477(2000)081<0427:TIEWAC >2.3.CO;2.

National Weather Service, 2013a: Record river flooding of April 2013. NWS Lincoln KILX, https://www.weather.gov/ilx/ apr2013flooding.

_, 2013b: The record flooding of April 17-18: Crests, rainfall, photos, and setup. NWS Chicago KLOT, https:// www.weather.gov/lot/2013Apr1718.

2014: United States flood loss report-Water year 2013. National Weather Service, 6 pp., https://www.nws.noaa.gov/os/ water/Flood\%20Loss\%20Reports/WY13\%20Flood\%20Loss\% 20Summary.pdf.

Thompson, D. W., and J. M. Wallace, 1998: The Arctic oscillation signature in the wintertime geopotential height and temperature fields. Geophys. Res. Lett., 25, 1297-1300, https://doi.org/ 10.1029/98GL00950.

Yarnell, D. L., 1935: Rainfall intensity-frequency data. U.S. Department of Agriculture Miscellaneous Publ. 204, 69 pp., https://naldc.nal.usda.gov/download/CAT87205951/PDF.

Yu, L., S. Zhong, L. Pei, X. Bian, and W. E. Heilman, 2016: Contribution of large-scale circulation anomalies to changes in extreme precipitation frequency in the United States. Environ. Res. Lett., 11, 044003, https://doi.org/10.1088/1748-9326/ 11/4/044003. 